\title{
Pulsed LED Light: Exploring the Balance between Energy Use and Nutraceutical Properties in Indoor-Grown Lettuce
}

\author{
Laura Carotti ${ }^{1}$, Giulia Potente ${ }^{2}$, Giuseppina Pennisi ${ }^{1}, * \mathbb{C}$, Karina B. Ruiz $^{3}{ }^{\mathbb{D}}$, Stefania Biondi ${ }^{4} \mathbb{D}$, \\ Andrea Crepaldi ${ }^{5}$, Francesco Orsini ${ }^{1} \mathbb{D}$, Giorgio Gianquinto ${ }^{1} \mathbb{D}$ and Fabiana Antognoni ${ }^{2}$ \\ 1 Department of Agricultural and Food Sciences, Alma Mater Studiorum-University of Bologna, viale Fanin 44, \\ 40127 Bologna, Italy; laura.carotti2@unibo.it (L.C.); f.orsini@unibo.it (F.O.); giorgio.gianquinto@unibo.it (G.G.) \\ 2 Department for Life Quality Studies, Rimini Campus, University of Bologna, Corso di Augusto 237, \\ 47921 Rimini, Italy; giulia.potente@unibo.it (G.P.); fabiana.antognoni@unibo.it (F.A.) \\ 3 Química y Farmacia, Facultad de Ciencias de la Salud, Universidad Arturo Prat, Av. Arturo Prat Ch 2120, \\ Iquique 1100000, Chile; karuiz@unap.cl \\ 4 Department of Biological, Geological and Environmental Sciences-University of Bologna, via Irnerio 42, \\ 40137 Bologna, Italy; stefania.biondi@unibo.it \\ 5 Flytech s.r.l., Via dell'Artigianato, 65, 32016 Belluno, Italy; andrea.crepaldi@flytech.it \\ * Correspondence: giuseppina.pennisi@unibo.it
}

check for updates

Citation: Carotti, L.; Potente, G.; Pennisi, G.; Ruiz, K.B.; Biondi, S.; Crepaldi, A.; Orsini, F.; Gianquinto, G.; Antognoni, F. Pulsed LED Light: Exploring the Balance between Energy Use and Nutraceutical Properties in Indoor-Grown Lettuce. Agronomy 2021, 11, 1106. https:// doi.org/10.3390/agronomy11061106

Academic Editors: Massimiliano D'Imperio, Francesco Serio,

Francesco Di Gioia, Agnieszka Sękara and Carla Sancho dos Santos

Received: 3 April 2021

Accepted: 24 May 2021

Published: 28 May 2021

Publisher's Note: MDPI stays neutral with regard to jurisdictional claims in published maps and institutional affiliations.

Copyright: (C) 2021 by the authors Licensee MDPI, Basel, Switzerland. This article is an open access article distributed under the terms and conditions of the Creative Commons Attribution (CC BY) license (https:/ / creativecommons.org/licenses/by/ $4.0 /)$.

\begin{abstract}
In indoor vertical farms, energy consumption represents a bottleneck for both a system's affordability and environmental footprint. Although switching frequency $(s f)$ represents a crucial factor in determining the efficacy of light emitting diodes (LED) lighting systems in converting electricity into light, the impact of $s f$ is still underexplored. The aim of this work was to investigate the effect of LEDs $s f$ on the productive and qualitative responses of lettuce (Lactuca sativa L.), also considering the resource use efficiency. Plants were grown for 14 days under red and blue LEDs $\left(215 \mu \mathrm{mol} \mathrm{m}{ }^{-2} \mathrm{~s}^{-1}\right.$ and 16/8 h light/dark, with a red:blue ratio of 3) characterized by two different $s f$ for the blue diode, namely high $s f(850 \mathrm{kHz})$ and low $s f(293 \mathrm{kHz})$. A fluorescent light (same light intensity and photoperiod) was included. LED sf did not alter plant morphological parameters, including fresh or dry biomass, leaf number, leaf area, or water use efficiency. A low $s f$ increased the energy use efficiency (EUE) by $40 \%$ as compared to high $s f$. The latter enhanced the leaf antioxidant capacity, as a consequence of increased concentrations of caftaric and chicoric acids, isoquercetin, and luteolin, consistent with the upregulation of a few genes related to the biosynthetic pathway of phenolic compounds ( $4 \mathrm{C} 3 \mathrm{H}$ and DFR). The study highlights that different $s f$ may significantly affect the EUE as well as crop nutritional properties.
\end{abstract}

Keywords: lettuce (Lactuca sativa); indoor farming; hydroponics; phenolic compounds; antioxidant capacity; LED lighting; pulsed light; flavonoids; antioxidative enzymes; gene expression

\section{Introduction}

The use of horticultural LED lighting systems has gained wide relevance in recent years thanks to the potential applications in indoor farming [1]. LED lights are durable, have a long lifetime, high radiant efficiency, and faster switching [2,3]. In addition, they make it possible to select and customize output spectral features, matching the plant's needs and allowing for high-quality crops [4,5], also in terms of nutraceutical properties (e.g., antioxidant capacity). On the other hand, the initial cost of LED lighting technology is higher as compared to other horticultural lighting typologies [6]. Electricity costs in indoor farms-also when LEDs are used-can account for 25 to $30 \%$ of the operational costs $[7,8]$. Improving horticultural LED energy use efficiency (EUE, i.e., plant biomass produced per unit of energy supplied) is, therefore, an imperative research priority for the large-scale adoption of indoor agriculture technologies $[9,10]$. A possible strategy to increase EUE comes from the substitution of a continuous lighting supply with pulsed 
light by modulating both the frequency and the duty ratio (i.e., the ratio between pulse duration (with the light turned on) and length of the light-dark cycle (whole cycle of light on and off) of LED lamps). This fostered the growth parameters in different crops (e.g., Brassica chinensis) exposed to intermittent lighting (60:15 min ratio of light:dark) [11]. In basil plants, intermittent lighting with dark periods every $10 \mathrm{~min}$ was shown not to alter growth/productive performance, thus allowing for significant increases in EUE [12]. In Arabidopsis seedlings, shorter pulse periods (down to 5:10 s of light:dark provided by red, blue, and far-red lights) were also observed to significantly reduce electricity requirements $(<50 \%)$ while preserving growth at similar values to that measured under continuous lighting (photoperiod of 12:12 h) [13]. Thanks to the advantages provided by LED technology, light pulses can also be extremely short and frequent, since LEDs can be turned fully off and fully on very rapidly, even with an interval of a $\mu$ s [14].

Lettuce (Lactuca sativa L.) is an economically important crop worldwide [15] and one of the most popular species grown in vertical farms [16]. Rapid growth and a short growing cycle have made lettuce a model crop for studying the interaction between plants and light [17]. Lettuce leaves are also a good source of phenolic compounds [18], mostly represented by hydroxycinnamic acid derivatives, with chicoric and caftaric acids as the major representatives of this sub-class, and flavonoids, especially flavonols. Several health benefits have been demonstrated for chicoric and caftaric acids [19-23], while the presence of flavonols in green tissues has been related to the high antioxidative activity in planta, deriving from their chemical structure [24]. In particular, the high ROS scavenging capacity of quercetin and kaempferol glycosides has been confirmed in some species, including lettuce [25] and Phillyrea latifolia [26]. Strategies to improve the nutraceutical content of indoor-grown crops are aimed at obtaining highly nutritional crops all year long, an important goal considering that in some lettuce cultivars [27] and in baby leaf lettuce [28], the concentration of phenolic compounds has been shown to change according to seasonality. In lettuce, as in most horticultural crops, red and blue light have been identified as the most efficient spectral regions for enhancing both growth and the concentration of nutraceutical compounds $[29,30]$. Studies on the optimal red:blue light ratio (RB) for lettuce identified $\mathrm{RB}=3$ as the combination providing both the highest yield and the highest flavonoid content, as compared to fluorescent light and LED light with other RB ratios. In addition, $\mathrm{RB}=3$ led to the greatest efficiency in terms of land, water, and energy use [31]. Optimal light intensity (200-250 mmol m${ }^{-2} \mathrm{~s}^{-1}$,) and photoperiod $\left(16 \mathrm{~h} \mathrm{~d}^{-1}\right)$ were also recently identified as critical factors influencing lettuce growth and nutraceutical content, as well as crop EUE [32,33].

Although numerous studies have targeted the photoregulation of plant growth and development, less information is available on the effects of LED light quality on associated gene expression. Blue, red, and white LEDs, individually or in combination, have been reported to influence the expression of key regulatory genes involved in the carotenoid and flavonoid biosynthetic pathways as reported in wheat sprouts [34], and in the antioxidant defense machinery, such as the ascorbate metabolism in post-harvest broccoli [35]. Given that LED lighting can affect the accumulation of non-enzymatic antioxidants, including phenylpropanoids, tocopherols, vitamin C, and ascorbate [36], it may be expected that the activities and the transcript levels of enzymatic antioxidants, such as catalase (CAT) and glutathione S-transferase (GST), may likewise be affected [37].

The present research builds on available information concerning the application of an optimized red and blue LED spectrum $(\mathrm{RB}=3)$ for lettuce cultivation by exploring the potential impact of pulsed light technology. The work defines how growth, the concentration of phenolic compounds, and the antioxidant capacity of hydroponically grown lettuce vary in response to two different switching frequencies $(s f)$ of the blue diode in an $\mathrm{RB}=3 \mathrm{LED}$ lighting system. The antioxidant capacity of leaf extracts and the expression of genes encoding for enzymes in the biosynthetic pathway of phenolic compounds and antioxidative enzymes were analyzed, with the final aim of increasing our knowledge of 
how resource use efficiency and the nutraceutical value of indoor-grown lettuce plants are regulated by LED pulsed light.

\section{Materials and Methods}

\subsection{Plant Material and Growth Conditions}

Plants were grown at the Department of Agricultural and Food Sciences of the University of Bologna (Italy). Seeds of green lettuce "Gentilina" (Lactuca sativa L. cv. Rebelina, Gautier, Eyragues, France) were germinated in polystyrene containers filled with a mixture of peat and vermiculite (70/30 v/v), under fluorescent lamps (TL-D90 De Luxe 950, Philips) providing a Photosynthetic Photon Flux Density (PPFD) of $215 \mu \mathrm{mol} \mathrm{m}^{-2} \mathrm{~s}^{-1}$ and a photoperiod of $16 \mathrm{~h} \mathrm{~d}^{-1}$. When the plants reached a two true leaf stage (14 days after sowing), the roots were washed and plantlets were transplanted into single-plant hydroponic systems [38] consisting of plastic jars $(1 \mathrm{~L})$ filled with a nutrient solution $(\mathrm{EC}=1.6, \mathrm{pH}=6.5)$ of the following composition: $\mathrm{NO}_{3}-\mathrm{N}, 14 \mathrm{mM} ; \mathrm{NH}_{4}-\mathrm{N}, 4.4 \mathrm{mM} ; \mathrm{P}, 1.0 \mathrm{mM} ; \mathrm{K}, 5.0 \mathrm{mM}$; S, $2.0 \mathrm{mM}$; Ca, 1.2 mM; Mg, 5.2 mM; Fe, $17.9 \mu \mathrm{M}$; Cu, $2.0 \mu \mathrm{M}$; Zn, $3.8 \mu \mathrm{M}$; B, $11.6 \mu \mathrm{M}$; $\mathrm{Mn}, 18.2 \mu \mathrm{M}$; and Mo, $0.5 \mu \mathrm{M}$. The nutrient solution was constantly aerated through air pumps (Airline 3, Haquoss, Turin, Italy, with an air exchange rate of $0.25 \mathrm{~L} \mathrm{~min}^{-1} \mathrm{jar}^{-1}$ ). After transplanting, the plants were grown in three separate compartments $\left(0.64 \mathrm{~m}^{2}\right.$ surface and $0.4 \mathrm{~m}^{3}$ volume) isolated by white opaque walls in a climate-controlled growth chamber (temperature $24 \pm 2{ }^{\circ} \mathrm{C}$, $\mathrm{RH} 55-70 \%$, and $450 \mathrm{ppm} \mathrm{CO}_{2}$ ). A planting density of 100 plants $\mathrm{m}^{-2}$ and a crop cycle length of 14 days from transplant to harvest were adopted [31].

\subsection{Light Treatments}

In two of the three compartments, lettuce plants were grown under dimmable LED lamps (Flytech s.r.l., Belluno, Italy) featuring red light (peak at $669 \mathrm{~nm}$ ) and blue light (peak at $465 \mathrm{~nm}$ ) emitting diodes. The lamps were set to supply a spectral composition with a red:blue ratio of $3(\mathrm{RB}=3)$, a light intensity of $215 \mu \mathrm{mol} \mathrm{m}{ }^{-2} \mathrm{~s}^{-1}$, and a photoperiod of $16 \mathrm{~h} \mathrm{~d}^{-1}$. The spectral distribution was measured using an illuminance spectrophotometer (CL-500A, Konica Minolta, Chiyoda, Tokyo, Japan). A photosynthetic photon flux sensor (with equal sensitivity to red and blue radiation), model QSO (Apogee instruments, Logan, UT, USA) connected with a ProCheck handheld reader (Decagon Devices Inc., Pullman, WA, USA) was used to set a PPFD $\left(\mu \mathrm{mol} \mathrm{m}^{-2} \mathrm{~s}^{-1}\right)$ over the plant canopy [31]. The light treatments consisted of the following two different switching frequencies $(s f)$ for the blue diode: a high $s f(850 \mathrm{kHz})$ and a low $s f(293 \mathrm{kHz})$; in the two treatments, the $s f$ for the red diode was similar (namely $437 \mathrm{kHz}$ and $443 \mathrm{kHz}$, respectively). A third light treatment with fluorescent light (FL), one of the traditional artificial light sources for indoor plant cultivation, was applied in the third compartment with the same light intensity and the same photoperiod as the LED light treatment.

\subsection{Growth Analysis and Resource Use Efficiency}

At harvest (14 days after transplanting), the leaf and root fresh weights per plant (g FW plant ${ }^{-1}$ ) were measured and the dry weights were quantified after drying the samples at $60^{\circ} \mathrm{C}$ for $72 \mathrm{~h}$. Dry matter was calculated as the ratio between leaf dry and fresh weights and expressed as a percent value. Plant leaf area was determined using a leaf area meter (LI-300, LI-COR, Lincoln, NE, USA), and Specific Leaf Area (SLA) was calculated as the ratio between the plant leaf area and the leaf dry weight. The leaf number per plant was also counted.

Water use was quantified for each plant and Water Use Efficiency (WUE) was determined as the ratio between plant fresh weight and the volume of water used and was expressed as $\mathrm{g} \mathrm{FW} \mathrm{L} \mathrm{L}^{-1} \mathrm{H}_{2} \mathrm{O}$. Lighting Energy Use Efficiency (EUE) was determined as the ratio between the final leaf fresh weight and the lamps' cumulative electricity consumption and was expressed as $\mathrm{g} F W \mathrm{kWh}^{-1}$. 


\subsection{Biochemical Determinations}

\subsubsection{Extraction Procedure for Phenolic Compounds}

Extraction of phenolic compounds from leaf material was performed as described by Llorach et al. [39], with some modifications. After drying, leaves collected from six plants per treatment were pooled and finely ground in a knife mill for $4 \times 30$ s periods. The fine powder was then subjected to the "coning and quartering" sampling procedure and two technical replicates were carried out. A 1-g aliquot of dried leaves was extracted with $20 \mathrm{~mL}$ of a mixture of methanol/water/formic acid (50/48/2 v/v/v). The suspension was mixed and sonicated for $15 \mathrm{~min}$ at $35^{\circ} \mathrm{C}$. After centrifugation for $30 \mathrm{~min}$ at $1400 \times g$, the supernatant was transferred into another tube and the pellet was extracted once again with the same procedure. Supernatants were merged, filtered through Grade $44(3 \mu \mathrm{m})$ ashless filter paper, evaporated to dryness, and re-suspended with the same extraction mixture to a $50 \mathrm{mg} \mathrm{mL}^{-1}$ concentration. The extract was filtered again through a syringe filter (nylon, $0.22 \mu \mathrm{m}$ pore diameter, Thermo Fisher Scientific, Carlsbad, CA, USA) and stored at $-20{ }^{\circ} \mathrm{C}$ until used for analyses.

\subsubsection{Determination of Total Phenolic Compounds and Total Flavonoids}

The Total Phenolic Content (TPC) of the leaf extracts was evaluated using FolinCiocalteu's reagent, as described by Singleton and Rossi [40], with some modifications. A mixture containing $100 \mu \mathrm{L}$ of diluted extract or standard, respectively, and $440 \mu \mathrm{L}$ of Folin-Ciocalteu's reagent (diluted 1:10 with distilled water) was incubated for $10 \mathrm{~min}$ at room temperature (RT). Then, $440 \mu \mathrm{L}$ of $7.5 \% \mathrm{Na}_{2} \mathrm{CO}_{3}$ was added and the mixture was incubated in the dark for $60 \mathrm{~min}$ at RT. Gallic acid was used as a standard, and a calibration curve was built in the $6.25-100 \mathrm{ppm}$ range. The absorbance was measured at $765 \mathrm{~nm}$ using a double-beam spectrophotometer (V-630 Jasco, Jasco Europe S.r.l., Cremella, Italy).

The Total Flavonoid Content (TFC) was evaluated according to the method described by Zhou et al. [41], with some modifications. A mixture containing $100 \mu \mathrm{L}$ of diluted extract or standard and $440 \mu \mathrm{L}$ of $0.066 \mathrm{M} \mathrm{NaNO}_{2}$ was left to react for 5 min at RT. Then, $60 \mu \mathrm{L}$ of $0.75 \mathrm{M} \mathrm{AlCl}_{3}$ was added and the mixture was incubated for $5 \mathrm{~min}$. Finally, $400 \mathrm{~mL}$ of $0.5 \mathrm{M} \mathrm{NaOH}$ was added and the mixture was incubated for $6 \mathrm{~min}$ at RT. The absorbance was measured at $510 \mathrm{~nm}$ and the TFC was calculated by interpolating with the calibration curve built with catechin as a standard, in a concentration range of 3.12-200 ppm.

\subsubsection{HPLC Analysis of Phenolic Compounds}

The extracts were injected into a Jasco (Tokyo, Japan) HPLC-DAD system, which consisted of a PU-4180 pump, an MD-4015 PDA detector, and an AS-4050 autosampler. The stationary phase was an Agilent (Santa Clara, CA, USA) Zorbax Eclipse Plus C18 reversed-phase column $(100 \mathrm{~mm} \times 3 \mathrm{~mm}$ I.D., $3.5 \mu \mathrm{m})$. The injection volume was $20 \mu \mathrm{L}$ for all of the determinations. The method used for the phenolic acids analysis was adapted from Llorach et al. [39], with some modifications. Elution was carried out with a mixture of solvent A (water/formic acid, 95/5 v/v) and solvent B (methanol), with a composition gradient ranging from 95 to $60 \%$ of solvent $\mathrm{A}$ and flowing at $0.5 \mathrm{~mL} \mathrm{~min}^{-1}$. The chromatograms were recorded at $329 \mathrm{~nm}$. For flavonoid analysis, the method used was the one described by Milinović et al. [42], with some modifications. Elution was carried out using a mixture of solvent A (water/formic acid, 95.5/4.5 v/v) and solvent B (acetonitrile), with a composition gradient ranging from 95 to $36 \%$ of solvent $\mathrm{A}$ and a flow rate of $0.5 \mathrm{~mL} \mathrm{~min}{ }^{-1}$. The identification was performed at $360 \mathrm{~nm}$.

\subsubsection{In Vitro Antioxidant Assays}

The 2,2'-diphenyl-1-picrylhydrazide (DPPH) assay was conducted on methanolic extracts using a Jasco V-630 double beam spectrophotometer, as described by BrandWilliams et al. [43]. An aliquot $(950 \mu \mathrm{L})$ of a DPPH methanolic solution $(0.11 \mathrm{mM})$ and $50 \mu \mathrm{L}$ of Trolox (Tx) solutions at different concentrations (in the 50-1000 $\mu \mathrm{M}$ range), were thoroughly mixed in a test tube. For sample analysis, $50 \mu \mathrm{L}$ of an appropriately diluted 
sample solution was used, and a blank was also made using $50 \mu \mathrm{L}$ of solvent. The vial was incubated in the dark at room temperature for $24 \mathrm{~h}$, then the absorbance of the solution was read at $515 \mathrm{~nm}$. The 2,2-azinobis (3-ethylbenzothiazoline-6-sulfonic acid) (ABTS) assay was conducted following the protocol of Thaipong et al. [44], using a Jasco V-630 double beam spectrophotometer. For both the DPPH and the ABTS assays, the calibration curves were set up by plotting the discoloration percentage (i.e., $\left[1-\left(\right.\right.$ ABS Tx/ABS blank) $\left.{ }^{*} 100\right)$ as a function of the Tx concentration. Trolox equivalents (TEs) of the samples were calculated by interpolation on the calibration curve. The oxygen radical absorbance capacity (ORAC) assay was conducted using a Perkin Elmer (Turku, Finland) Viktor X3 multilabel plate reader, as described by $\mathrm{Ou}$ et al. [45]. The Trolox equivalents were calculated from the relative area under the curve of the emission intensity vs. time plot.

\subsection{Real-Time Quantitative Reverse Transcription-Polymerase Chain Reaction (RT-qPCR)}

Total RNA extraction and RT-qPCR analysis were performed according to Ruiz et al. [46]. Total RNA was extracted from the leaves of three separate plants (i.e., three biological replicates) by performing two separate extractions of $0.1 \mathrm{~g}$ FW for each replicate. RNA yield and purity were checked using UV absorption spectra, whereas RNA integrity was determined using electrophoresis on agarose gel. DNA was removed using the TURBO DNA-free TM (Applied Biosystems, Foster City, CA, USA) from about $10 \mu \mathrm{g}$ aliquots of total RNA. First-strand cDNA was synthesized from $6 \mu \mathrm{g}$ of the DNase-treated RNA using the High-Capacity cDNA Kit (Applied Biosystems) with random primers. The reaction mixture for the qPCR analysis was made in a final volume of $25 \mu \mathrm{L}$, containing $3 \eta \mathrm{ng}$ of cDNA, 5 pmol of each primer, and $12.5 \mu \mathrm{L}$ of the PowerUp SYBR Green PCR master mix (Applied Biosystems), according to the manufacturer's instructions. The actin gene was used as a reference [47] to normalize and estimate the up- or down-regulation of the target genes. The sequences of gene coding for phenylalanine ammonia lyase (PAL), chalcone synthase (CHS), flavonol synthase (FLS), a putative 4-coumaric acid $3^{\prime}$-hydroxylase (4C3H), dihydroflavonol 4-reductase (DFR), glutathione-S-transferase (GST), and catalase (CAT) were obtained from the NCBI database. Primer sequences for all of the analyzed genes are listed in Table S1 (Supplementary Material). PCRs were carried out using a StepOnePlus RM 7500 Fast (Applied Biosystems) for $2 \mathrm{~min}$ at $50^{\circ} \mathrm{C}, 2 \mathrm{~min}$ at $95^{\circ} \mathrm{C}$, and then for 40 cycles as follows: $95^{\circ} \mathrm{C}$ for $3 \mathrm{~s}$ and $60^{\circ} \mathrm{C}$ for $30 \mathrm{~s}$. Fold changes in RNA expression in the LED light-treated samples as compared to FL results were estimated using threshold cycles and analyzed using the comparative threshold cycle method, also known as the $2^{-\Delta \Delta \mathrm{Ct}}$ method [48].

\subsection{Statistical Analysis}

Morphological measurements were performed on six plants per light treatment, while for the biochemical determinations and the RT-qPCR, three plants were considered. Data were analyzed using a one-way ANOVA and means were compared using the LSD test, at a 5\% significance level. For the analysis of the transcript level data, a one-way ANOVA was applied followed by Fisher's test, at a 5\% significance level.

\section{Results and Discussion}

\subsection{Low Switching Frequencies Improve Energy Use Efficiency}

Plant photosynthesis is composed by alternating light and dark reactions. Light reactions, in which light energy is harvested and transformed into chemical energy products, occur very quickly (in the range of nanoseconds to milliseconds) while dark reactions, in which products of the first phase are used to assimilate $\mathrm{CO}_{2}$, occur more slowly (from seconds to minutes [12]). To date, the main research gap that hinders the use of pulsed light technology, through LED illumination systems that can provide very rapid flashes, is the need for identifying light emission frequencies that improve, or at least do not impair, plant growth and final yield performances. By extending the duration of the dark periods between pulses one can save electricity, thereby reducing the costs of the overall plant 
growing system. In this study, the morphological and growth parameters investigated were not significantly affected by the adopted lighting regimes (Table 1). The absence of statistical significance may be due to the high variability among samples (Table 1 ) and to the low number of samples used in the experiment $(n=6)$. Therefore, these parameters will need to be explored in future research using a higher number of replicates. Jishi et al. [49] developed and validated a kinetic model for lettuce plants, enabling an estimate net photosynthetic rate under different pulsed light conditions, characterized by different PPFDs, frequencies, and duty ratios. Accordingly, the photosynthetic rate of the leaves grown under low pulsed light frequency and duty ratio was lower than that of the leaves grown under continuous light and was quantitatively comparable to continuous light when high pulsed light and duty ratio were applied. According to former research on lettuce plants performed by Kanechi et al. [14], LED light frequencies from 1.3 to $20 \mathrm{kHz}$ could lead to an increase of up to $20 \%$ in shoot FW and leaf area compared to lower frequencies (from 0.5-500 Hz) and continuous light. The effect of LED sf on growth and lettuce morphology needs further validation, also considering that, under our experimental conditions, both the high and low sf used were much higher than the frequencies tested by Kanechi et al. [14]. The leaf area of the plants grown under LED treatments was significantly lower than in those grown under FL (Table 1), without differences among the LED sf. Indeed, a higher leaf area for lettuce plants grown under FL as compared to those grown under LED lights has already been observed, possibly as a strategy to improve light interception when photosynthetic efficiency is lower [31].

Table 1. Effect of different lighting treatments on morphological parameters, water use, and water use efficiency of indoor-grown lettuce plants $(n=6)$. Different letters indicate significant differences at $p \leq 0.05 . \mathrm{SD}=$ standard deviation.

\begin{tabular}{|c|c|c|c|c|c|c|c|}
\hline & High $s f$ & SD & Low $s f$ & SD & FL & SD & $p$-Value \\
\hline Leaf FW (g plant ${ }^{-1}$ ) & $63.6 \mathrm{a}$ & 10.9 & $57.7 \mathrm{a}$ & 10.0 & $58.4 \mathrm{a}$ & 8.6 & 0.53 \\
\hline Root FW (g plant $\left.{ }^{-1}\right)$ & $11.3 \mathrm{a}$ & 4.7 & $7.4 \mathrm{a}$ & 1.8 & $7.4 \mathrm{a}$ & 1.6 & 0.06 \\
\hline Leaf DW (g plant $\left.{ }^{-1}\right)$ & $3.5 \mathrm{a}$ & 1.0 & $2.7 \mathrm{a}$ & 0.6 & $2.9 \mathrm{a}$ & 0.9 & 0.25 \\
\hline Root DW (g plant ${ }^{-1}$ ) & $0.6 \mathrm{a}$ & 0.4 & $0.3 \mathrm{a}$ & 0.1 & $0.3 \mathrm{a}$ & 0.1 & 0.05 \\
\hline Leaf DM (\%) & $5.6 \mathrm{a}$ & 1.4 & $4.7 \mathrm{a}$ & 0.2 & $4.9 \mathrm{a}$ & 1.0 & 0.32 \\
\hline Leaf number $(n)$ & $12.7 \mathrm{a}$ & 3.4 & $15.2 \mathrm{a}$ & 1.2 & $15.2 \mathrm{a}$ & 1.6 & 0.12 \\
\hline Leaf area $\left(\mathrm{cm}^{2}\right)$ & $965.4 \mathrm{~b}$ & 219.5 & $1062.5 \mathrm{~b}$ & 167.3 & $1239.1 \mathrm{a}$ & 107.4 & 0.04 \\
\hline WU (L plant $\left.{ }^{-1}\right)$ & $1.2 \mathrm{a}$ & 0.1 & $1.1 \mathrm{a}$ & 0.1 & $1.1 \mathrm{a}$ & 0.1 & 0.19 \\
\hline WUE $\left(\mathrm{g} \mathrm{FW} \mathrm{L}^{-1} \mathrm{H}_{2} \mathrm{O}\right)$ & $54.6 \mathrm{a}$ & 10.0 & $53.9 \mathrm{a}$ & 11.3 & $55.1 \mathrm{a}$ & 9.4 & 0.98 \\
\hline
\end{tabular}

$\overline{\text { FW }}$ = Fresh Weight; DW = Dry Weight; DM = Dry Matter Content; WU = Water Use; WUE = Water Use Efficiency.

Water use efficiency in a closed plant production system can be up to 50 times greater than in a greenhouse [1], a crucial element in environments where access to water is scarce [50], especially considering the water shortage that many urban areas will face in the coming years due to climate change [51]. In our experiments, the tested lighting regimes did not affect either water use (values between 1.1 and $1.2 \mathrm{~L} \mathrm{H}_{2} \mathrm{O}$ plant $^{-1}$, Table 1) or WUE (values between 53.9 and $55.1 \mathrm{FW} \mathrm{L}^{-1} \mathrm{H}_{2} \mathrm{O}$, Table 1), with comparable values in plants grown with ahigh $s f$, a low $s f$, and under FL. The WUE values are very interesting, especially when compared to the performance in terms of WUE for lettuce production in an open field (3-20 g FW L ${ }^{-1} \mathrm{H}_{2} \mathrm{O}$ ) or in a greenhouse (5-60 $\mathrm{g} \mathrm{FW} \mathrm{L}^{-1} \mathrm{H}_{2} \mathrm{O}$ ) [9].

EUE is a critical parameter for indoor cultivation systems, although a high potential for improvement is associated with light spectral features (light quality, intensity, and photoperiod) [9]. With reference to spectral quality, when a red and blue spectrum is used, increasing the percentage of red increases EUE up to a maximum, suggesting an optimal response function, thanks to the enhancement of shoot DW [7,31]. Here, we combined an optimized light spectrum $(\mathrm{RB}=3)$, light intensity $\left(215 \mu \mathrm{mol} \mathrm{m}{ }^{-2} \mathrm{~s}^{-1}\right)$, and photoperiod $\left(16 \mathrm{~h} \mathrm{day}^{-1}\right)$ and achieved a further improvement in EUE using a low $s f$. Accordingly, in lettuce plants grown under a low $s f$, EUE reached values of up to $123 \mathrm{~g} \mathrm{FW} \mathrm{kWh}^{-1}$, with a $42 \%$ increase compared to plants grown under a high $s f\left(86.5 \mathrm{~g} \mathrm{FW} \mathrm{kWh}^{1}\right)$ and 2.7 -fold compared to plants grown under FL (45 $\left.\mathrm{g} \mathrm{FW} \mathrm{kWh}^{-1}\right)$ (Figure 1). 


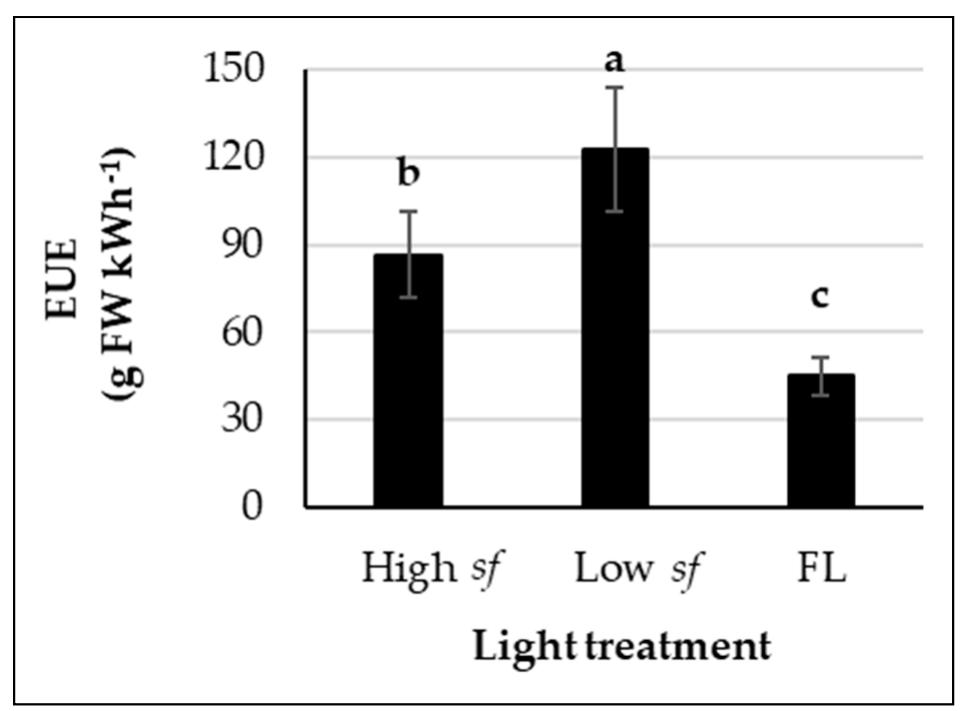

Figure 1. Effect of different lighting treatments on the energy use efficiency (EUE, $\mathrm{g} \mathrm{FW} \mathrm{kWh}{ }^{-1}$ ) of indoor-grown lettuce plants $(n=6)$. Vertical bars represent standard deviation. Different letters indicate significant differences at $p \leq 0.05$.

\subsection{High Switching Frequencies Enhance Phenolic Compounds and Total Antioxidant Capacity}

In recent years, consumer demand for healthy and antioxidant-rich food is increasing [52] in response to a growing awareness of the relevance that functional foods rich in phenolic compounds (e.g., flavonoids and hydroxycinnamic acids) play in preserving human health $[53,54]$. The concentration of phenolics in plant tissues is the combined result of genetic components, environmental conditions, growing techniques, and the interaction between these factors [55]. Light is one of the environmental factors regulating the synthesis, turnover, and degradation of antioxidant compounds in plants [56]. Different frequencies of supplemental monochromatic LED lighting $(2,32,256$ and $1024 \mathrm{~Hz}$, with a duty cycle of $50 \%$ ) significantly affected the TPC and the antioxidant activity of several microgreen species, such as basil, pak choi, mustard, and tatsoi, thus improving their nutraceutical properties $[57,58]$. On the other hand, there is no information regarding the effect of pulsed light on these parameters in lettuce.

In our work, although the TPC and the TFC did not vary significantly when the $s f$ was modified (data not shown), changes in the concentrations of specific phenolic compounds were revealed using HPLC-DAD analysis (Figure 2). Possibly, this is due to the scarce specificity of UV-Vis spectrophotometric methods commonly used to assay the TPC or the TFC, as recently emphasized by Granato et al. [59], where the need for more specific measurements when evaluating changes in secondary metabolite patterns was underlined. In lettuce, chicoric acid represents more than $55 \%$ of total caffeic acid derivatives [25] and, together with caffeic acid and three more caffeic acid derivatives, constitute $93 \%$ of total polyphenols found in greenhouse-grown lettuces. The hereby presented results show that a high $s f$ caused a significant increase in the levels of chicoric acid (Figure 2a) and caftaric acid (Figure 2b), while a low $s f$ treatment did not affect their concentrations as compared to FL. Chicoric acid levels were about eight-fold higher under a high $s f$ treatment as compared to leaves of plants grown with FL, and caftaric acid was two-fold higher. A similar response was observed for flavonoids, amongst which the most abundant compounds were isoquercetin, rutin, and luteolin. In this case, the effect varied depending on the compound. While the rutin levels were comparable under all light treatments (data not shown), high $s f$ LED light increased isoquercetin (Figure 2c) and luteolin concentrations (Figure 2d) by more than 15- and 50-fold, respectively, as compared to FL. Considering indoor-grown lettuces, the levels of caftaric acid detected in our lettuce leaves were very similar to those reported by Rouphael et al. [60], while lower levels of chicoric acid were found, if compared to other authors [61]. These discrepancies are not surprising, since 
several parameters were shown to have a great impact on the extraction efficiency of these metabolites, such as sampling, sample preparation procedure (freeze-dried vs. oven-dried), solvent-to-solid ratio used for extraction, duration of extraction, and sonication treatment applied, among others [62].

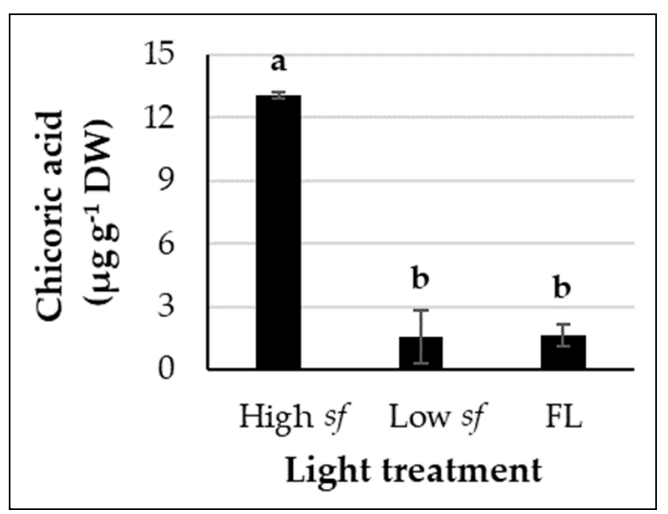

(a)

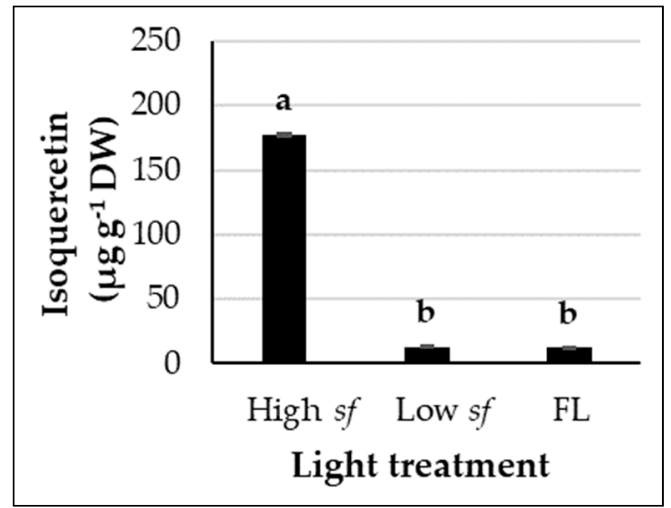

(c)

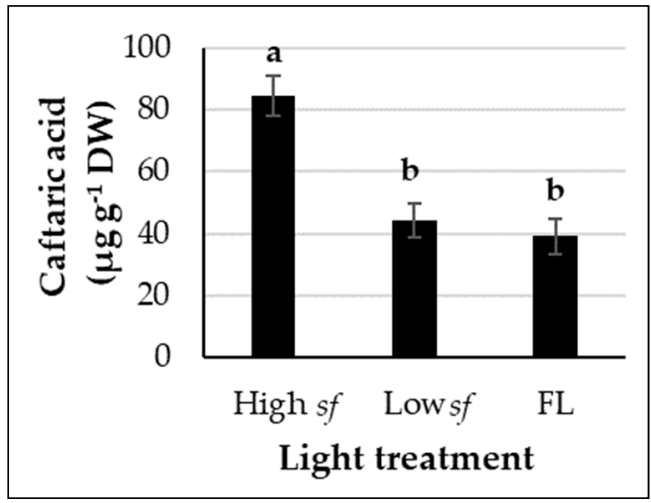

(b)

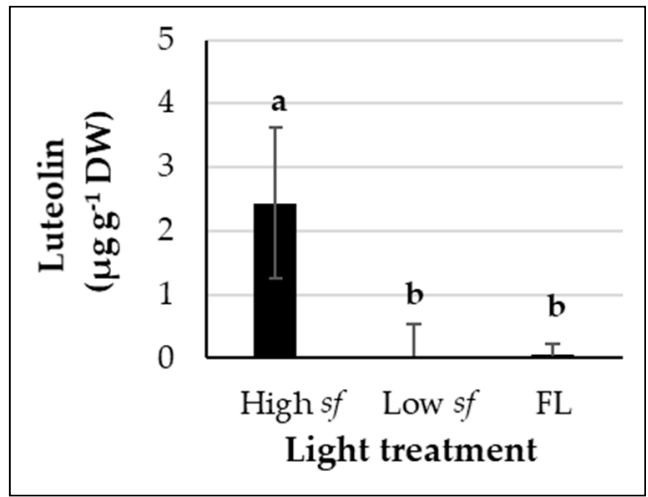

(d)

Figure 2. Effect of different lighting treatments on the concentration of the most abundant phenylpropanoids detected in lettuce leaves $(n=3)$, as follows: chicoric acid (a), caftaric acid (b), isoquercetin (c), and luteolin (d). Vertical bars represent standard deviations. Different letters indicate significant differences at $p \leq 0.05$.

Phenolic compounds are involved in many processes of plant physiology, being an important component in plant responses to environmental stresses and playing a role as antioxidants and oxygen scavengers [55]. For these reasons, in addition to the nutraceutical aspect, an increase in phenolic compounds in plants is advantageous as they can play a protective role against abiotic and biotic stresses [24,55]. In particular, flavonoids and cinnamic acid derivatives (to which caffeic acid and its derivatives belong) also exert photoprotective functions. In our work, the use of a high $s f$ may have acted as an abiotic stressor, resulting in an increased synthesis of flavonoids and cinnamic acid derivatives to protect the photosystems. In order to investigate the mechanisms leading to an enhanced production of phenolic compounds, in future research, measurements of the chlorophyll fluorescence signal could be performed. This would allow for photosynthetic activity to be measured and changes in heat dissipation occurring with different $s f$ to be monitored.

Flavonoids and cinnamic acid derivatives are synthetized via the phenylpropanoid pathway (Figure S1, Supplementary Material). Their biosynthesis is controlled by the regulation of genes encoding for key enzymes in the pathway, the first of which is phenylalanine ammonia-lyase (PAL) that catalyzes the first step in the pathway [63]. Here, although the expression of PAL was downregulated under a low $s f$ and unaffected by a high $s f$ as compared to the FL and FLS, encoding for flavonol synthase, was unaffected by the lighting regimes, the trend observed that the concentration of some phenolic compounds reflected 
the transcript levels of the genes involved in the production of hydroxycinnamates and some flavonoid subgroups. Thus, $4 \mathrm{C} 3 \mathrm{H}$, encoding for 4-coumaric acid $3^{\prime}$-hydroxylase, an enzyme further down the biosynthetic pathway of caffeic acid derivatives than PAL [64], was more highly expressed under a high $s f$ and this was related to increased amounts of chicoric and caftaric acids. DFR, which leads to the biosynthesis of flavan-4-ols and flavan-3,4-diols (not determined in the hereby presented study), was also up-regulated by a high sf (Figure 3).

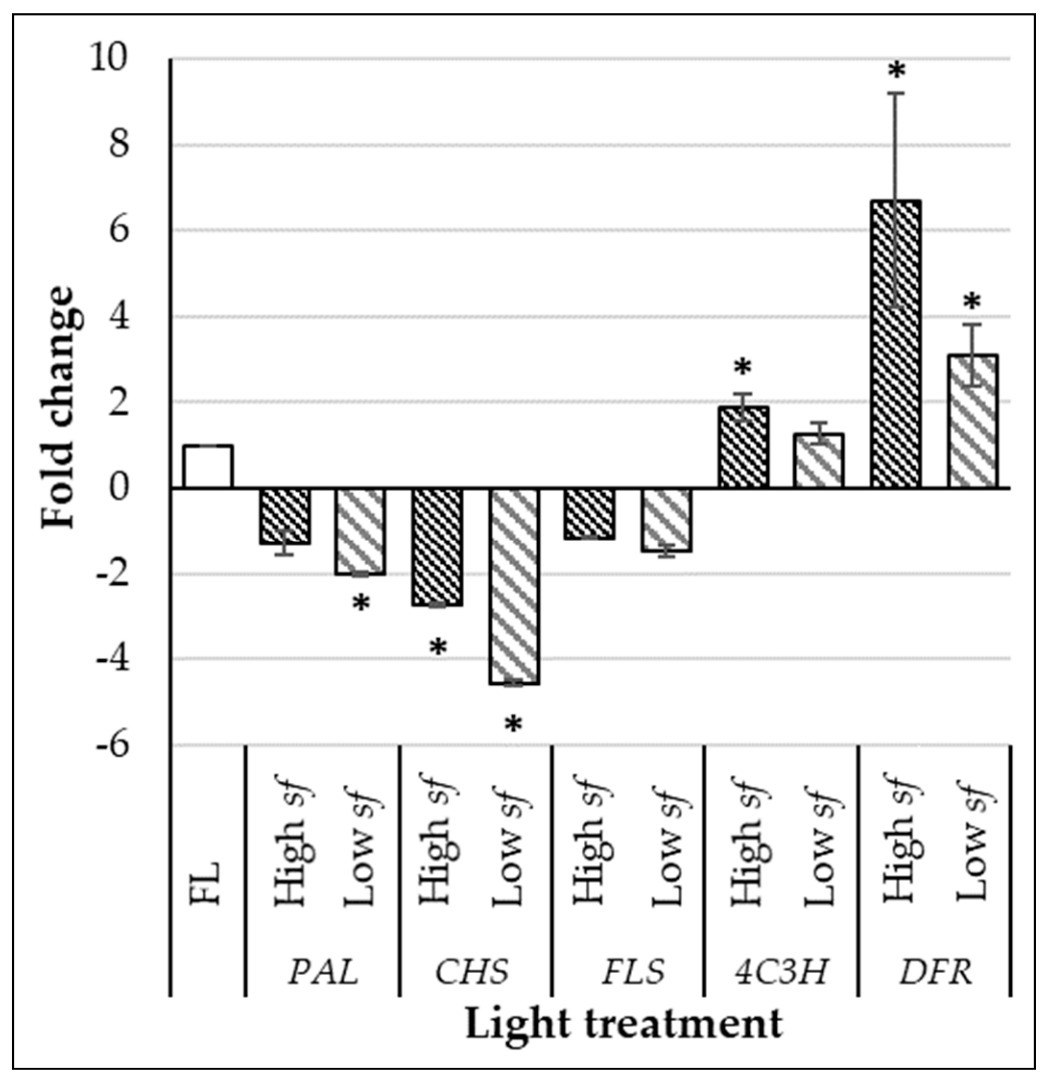

Figure 3. Effect of different lighting treatments on the expression of genes encoding for enzymes in the biosynthetic pathway of phenolic compounds in lettuce leaves $(n=3)$ expressed as foldchanges relative to the fluorescent light (FL, arbitrarily set at 1$)$. PAL = phenylalanine ammonialyase; $\mathrm{CHS}=$ chalcone synthase; FLS = flavonol synthase; $4 \mathrm{C} 3 \mathrm{H}=4$-coumaric acid 3 '-hydroxylase; $\mathrm{DFR}=$ dihydroflavonol 4-reductase. Vertical bars represent standard errors. ${ }^{*}$ indicates significant differences at $p \leq 0.05$.

Interestingly, leaves grown under high sf LED light possessed a significantly higher Total Antioxidant Capacity (TAC) compared to plants grown with FL according to all of the assays used, with increases ranging from 60\% (ORAC, DPPH) to 88\% (ABTS) (Figure 4). In two varieties of Brassica rapa, Vastakaite et al. [58] reported an increase in the antioxidant activity for all of the treatments with supplemental pulsed LED light (ranging from 2 to $1024 \mathrm{~Hz}$ ). On the contrary, results of the antioxidant assays performed on the extracts of leaves irradiated with a low $s f$ were not univocal. According to the DPPH and ORAC tests, no significant changes in the TAC were observed compared to the leaves grown under FL (Figure $4 \mathrm{a}, \mathrm{c})$, while according to the ABTS test, the TAC was enhanced (+40\%) compared to FL (Figure $4 b)$. 


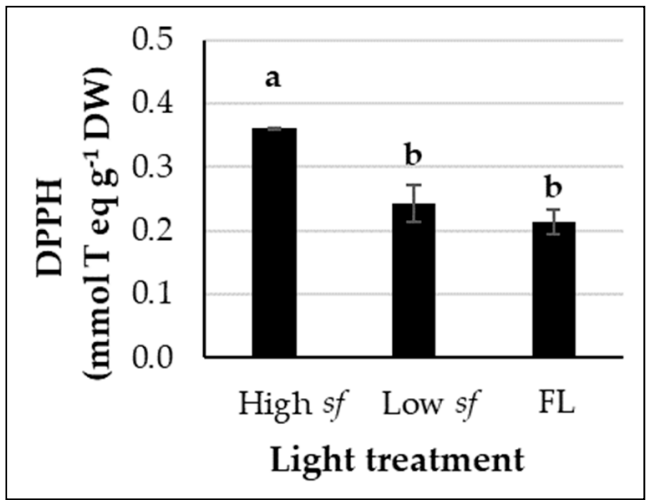

(a)

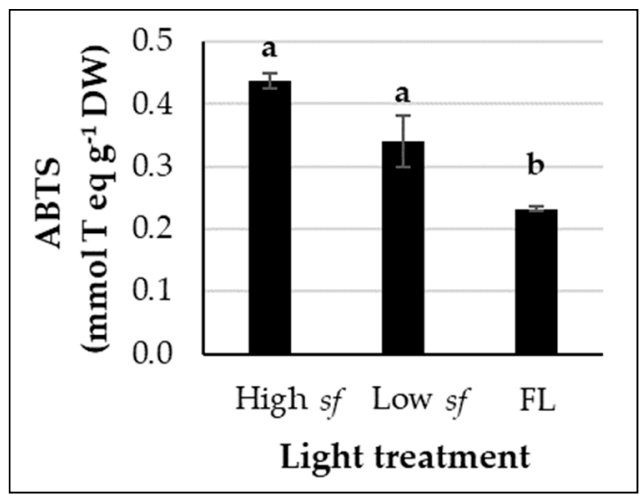

(b)

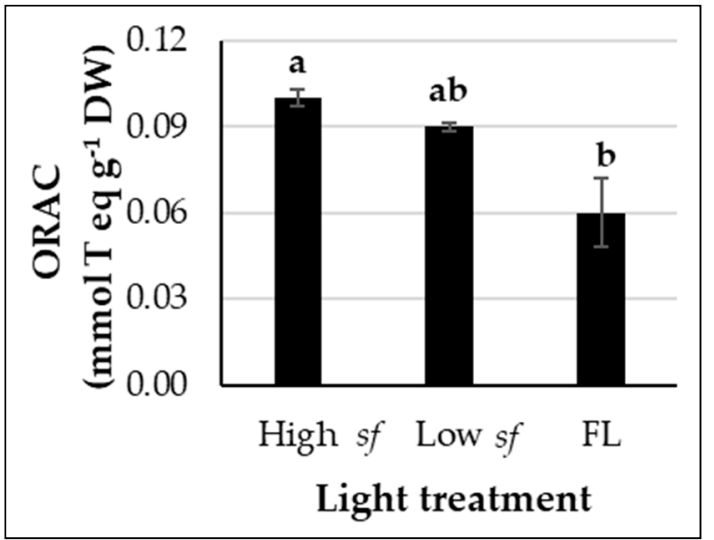

(c)

Figure 4. Effect of different lighting treatments on the Total Antioxidant Capacity of leaf extracts $(n=3)$ measured using three different assays, namely DPPH (a), ABTS (b), and ORAC (c). All of the values are expressed as mmol Trolox equivalents (T eq) $\mathrm{g}^{-1} \mathrm{DW}$. Vertical bars represent standard deviations. Different letters indicate significant differences at $p \leq 0.05$.

The antioxidant activity of plant extracts can vary depending on the oxidation conditions and the methods of measurement [65], as shown in the hereby presented study when comparing results on the effect of low sf using the DPPH assay with those obtained from the ORAC and ABTS assays. This is not surprising, since these assays differ in their underlying chemical reaction and in the radical source used [66]. According to a comprehensive study on 927 vegetables [67], the ORAC assay is considered to be a more biologically relevant assay compared to DPPH and ABTS, since it is based on the chain-breaking activity against the peroxyl radicals formed in cells during lipid peroxidation. Thus, the increase in the TAC observed in lettuce leaves grown under a low sf compared to leaves grown with FL is probably correlated to the increased abundance of some polar components other than those detected by us. To elucidate the nature of these metabolites, a more comprehensive investigation based on untargeted techniques would be needed. Moreover, despite the lack of substantial changes in the overall concentrations of the phenolics and flavonoids (TPC and TFC), a high sf was able to induce a significant enhancement in the TAC. This confirms the fact that this parameter also relies on the structure of single molecules, whose contribution depends on their specific antiradical effect [68,69] and may be justified by the fact that our analyses do not include some key antioxidants (e.g., ascorbic acid, and tocopherols).

As highlighted by Fu et al. [70], the activity level of certain antioxidative enzymes, including catalase, is an indicator of whether and to what extent plants are stressed (e.g., light stress). Thus, in order to check for possible light-induced oxidative stress under the different lighting regimes, the expression of the following two genes encoding for antioxidative enzymes were investigated: GST, encoding for glutathione S-transferases, and CAT, encoding for catalase. GST belongs to a superfamily of enzymes catalyzing a 
variety of reactions involved in tolerance to abiotic stresses and, indirectly, acts in ROS removal [71]. Transcript levels of GST were unaffected by the different lighting regimes (Figure 5). Instead, CAT, one of the main enzymes metabolizing stress-induced ROS, in particular by converting $\mathrm{H}_{2} \mathrm{O}_{2}$ to $\mathrm{O}_{2}$ and water [72], was down-regulated in plants grown under low $s f$ LED light compared to FL (Figure 5).

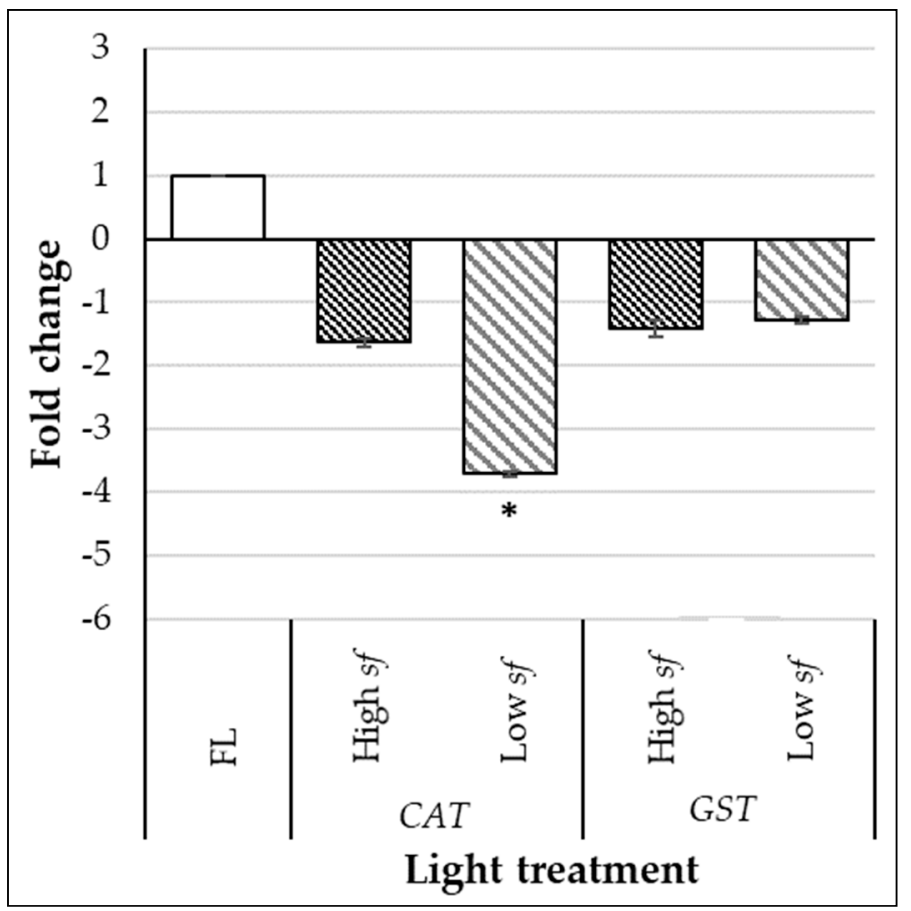

Figure 5. Effect of different lighting treatments on the expression of genes encoding for antioxidant enzymes in lettuce leaves $(n=3)$ expressed as fold-changes relative to the fluorescent light (FL, arbitrarily set at 1$)$. CAT $=$ catalase; GST $=$ glutathione s-transferase. Vertical bars represent standard errors. ${ }^{*}$ indicates significant differences at $p \leq 0.05$.

Since the plants appeared healthy and their growth was not inhibited (Table 1), the lack of effect or down-regulation of the genes coding for antioxidant enzymes suggest either that under both high and low $s f$ LED lighting the plants were not subjected to oxidative stressinducing conditions, or, that the increased concentrations of non-enzymatic antioxidants, including some phenylpropanoids, may have contributed to protecting the plants from possible light stress.

\section{Conclusions}

In the present work, the potential impact of pulsed light technology under a previously optimized red and blue LED spectrum $(\mathrm{RB}=3)$ for indoor lettuce cultivation was explored. Under a low $s f$, EUE was significantly improved compared to plants grown under a high $s f$ and, especially when compared to plants grown under FL, without compromising the final yield nor WUE, indicating that this could represent an optimal condition in terms of energy costs. In lettuce leaves grown with a low $s f$, the content of the main phenylpropanoids analyzed and the TAC were comparable to those of plants grown under FL. However, plants grown with a high $s f$ revealed a significant increase in the main phenolic compounds found in lettuce leaves (i.e., caffeic acid derivatives) as well as in the TAC, thereby contributing to the nutraceutical properties of the crop. This work describes, for the first time, the effect of different $s f$ of LED light on the expression of the genes coding for enzymes in the phenylpropanoid pathway. In particular, it reveals that a high $s f$ enhanced the transcript abundance of the enzymes closely related to the biosynthesis of caffeic acid derivatives and flavanols. The expression of the genes encoding for the antioxidative enzymes CAT 
and GST suggested that the plants, grown with either a high or a low $s f$, did not face any oxidative stress. In summary, a low $s f$ can lead to a significant energy saving while obtaining the same yield. On the other hand, a low $s f$ does not reinforce the nutraceutical content of lettuce leaves, which is, instead, enhanced by a high $s f$. The present results point to the need for major efforts in achieving a balance between energy use and the nutraceutical properties of indoor-grown crops through a deeper understanding of the physiological, biochemical, and molecular responses of plants to pulsed LED light technology.

Supplementary Materials: The following are available online at https:/ / www.mdpi.com/article/10 .3390/agronomy11061106/s1: Figure S1, Phenylpropanoid biosynthetic pathway involving anthocyanins and flavonoids. In bold the biosynthetic enzymes. PAL, phenylalanine ammonia lyase; $\mathrm{C} 4 \mathrm{H}$, cinnamic acid 4-hydroxylase; 4C3H, 4-coumaric acid 3-hydroxylase; 4CL, 4-coumarate-CoA ligase; $\mathrm{CHS}$, chalcone synthase; $\mathrm{CHI}$, chalcone isomerase; $\mathrm{F} 3 \mathrm{H}$, flavanone 3-hydroxylase; $\mathrm{F}^{\prime} \mathrm{H}$, flavonoid 3'-hydroxylase; FLS, flavonol synthase; DFR, dihydroflavonol 4-reductase; LAR, leucoanthocyanidin reductase; LDOX, leucoanthocyanidin dioxygenase; ANR, anthocyanidin reductase; UFGT, UDPglucose flavonoid 3-O-glucosyltransferase; Table S1, List of oligonucleotides used in this study for RT-qPCR analysis.

Author Contributions: Conceptualization, F.O. and G.P. (Giuseppina Pennisi); methodology, F.O., G.P. (Giuseppina Pennisi) and G.P. (Giulia Potente); formal analysis, G.P. (Giuseppina Pennisi), G.P. (Giulia Potente), K.B.R., and L.C.; resources, A.C.; data curation, G.P. (Giuseppina Pennisi), G.P. (Giulia Potente) and K.B.R.; writing-original draft preparation, L.C. and G.P. (Giuseppina Pennisi); writing-review and editing, S.B., F.A., F.O., G.G., and G.P. (Giuseppina Pennisi); visualization, G.P. (Giuseppina Pennisi); supervision, S.B., F.A., F.O., and G.G.; funding acquisition, F.O., S.B., and F.A. All authors have read and agreed to the published version of the manuscript.

Funding: The research leading to this publication has received funding from the European Union's Horizon 2020 Research and Innovation Programme under Grant Agreement No. 862663, from the Emilia Romagna Region within the Project "Nutraceutical Indoor Farming in Emilia Romagna through Artificial Intelligence Sensoring" (DGR n. 255, 30/03/2020, POR-FSE 2014-2020, objective 10, priority 10.2), and from the University of Bologna funds for "Ricerca Fondamentale Orientata". K.B.R. was the recipient of grants from the University of Bologna (No. Rep. n. 12 Prot. n.290 2 July 2018) and from CONICYT, Chile (PAI79170093).

Institutional Review Board Statement: Not applicable.

Informed Consent Statement: Not applicable.

Acknowledgments: Authors would like to thank Giorgia Giacobbi (undergraduate student) for her technical contribution.

Conflicts of Interest: A.C. was employed by the Flytech s.r.l. company. The other authors declare no conflict of interest.

\section{References}

1. Kozai, T. Sustainable plant factory: Closed plant production systems with artificial light for high resource use efficiencies and quality produce. Acta Horticult. 2013, 1004, 27-40. [CrossRef]

2. $\mathrm{Xu}, \mathrm{Y}$. Nature and source of light for plant factory. In Plant Factory Using Artificial Light; Elsevier: Amsterdam, The Netherlands, 2019; pp. 47-69.

3. Massa, G.D.; Kim, H.; Wheeler, R.M.; Mitchell, C.A. Plant Productivity in Response to LED Lighting. HortScience 2008, 43, 1951-1956. [CrossRef]

4. Lobiuc, A.; Vasilache, V.; Oroian, M.; Stoleru, T.; Burducea, M.; Pintilie, O.; Zamfirache, M.-M. Blue, Red LED Illumination Improves Growth and Bioactive Compounds Contents in Acyanic and Cyanic Ocimum basilicum L. Microgreens. Molecules 2017, 22, 2111. [CrossRef]

5. Urrestarazu, M.; Najera, C.; del Mar Gea, M. Effect of the Spectral Quality and Intensity of Light emitting Diodes on Several Horticultural Crops. HortScience 2016, 51, 268-271. [CrossRef]

6. Nelson, J.A.; Bugbee, B. Economic analysis of greenhouse lighting: Light emitting diodes vs. high intensity discharge fixtures. PLoS ONE 2014, 9, e99010. [CrossRef]

7. Kong, Y.; Nemali, A.; Mitchell, C.; Nemali, K. Spectral Quality of Light Can Affect Energy Consumption and Energy-use Efficiency of Electrical Lighting in Indoor Lettuce Farming. Hort. Sci. 2019, 54, 865-872. [CrossRef] 
8. Yokoyama, R. Energy Consumption and Heat Sources in Plant Factories. In Plant Factory Using Artificial Light; Elsevier: Amsterdam, The Netherlands, 2019; pp. 177-184.

9. Orsini, F.; Pennisi, G.; Zulfiqar, F.; Gianquinto, G. Sustainable use of resources in plant factories with artificial lighting (PFALs). Eur. J. Hortic. Sci. 2020, 85, 297-309. [CrossRef]

10. Orsini, F.; Pennisi, G.; Michelon, N.; Minelli, A.; Bazzocchi, G.; Sanyé-Mengual, E.; Gianquinto, G. Features and Functions of Multifunctional Urban Agriculture in the Global North: A Review. Front. Sustain. Food Syst. 2020, 4, 562513. [CrossRef]

11. Harun, A.N.; Ani, N.N.; Ahmad, R.; Azmi, N.S. Red and blue LED with pulse lighting control treatment for Brassica chinensis in Indoor farming. In Proceedings of the IEEE Conference on Open Systems (ICOS), Kuching, Malaysia, 2-4 December 2013; pp. 231-236.

12. Avgoustaki, D.D.; Li, J.; Xydis, G. Basil plants grown under intermittent light stress in a small-scale indoor environment: Introducing energy demand reduction intelligent technologies. Food Control 2020, 118, 107389. [CrossRef]

13. Song, S.; Kusuma, P.; Carvalho, S.D.; Li, Y.; Folta, K.M. Manipulation of seedling traits with pulsed light in closed controlled environments. Environ. Exp. Bot. 2019, 166, 103803. [CrossRef]

14. Kanechi, M.; Maekawa, A.; Nishida, Y.; Miyashita, E. Effects of pulsed lighting based light-emitting diodes on the growth and photosynthesis of lettuce leaves. Acta Hortic. 2016, 1134, 207-214. [CrossRef]

15. van Treuren, R.; van Eekelen, H.D.L.M.; Wehrens, R.; de Vos, R.C. Metabolite variation in the lettuce gene pool: Towards healthier crop varieties and food. Metabolomics 2018, 14, 146. [CrossRef]

16. Tamura, Y.; Mori, T.; Nakabayashi, R.; Kobayashi, M.; Saito, K.; Okazaki, S.; Wang, N.; Kusano, M. Metabolomic Evaluation of the Quality of Leaf Lettuce Grown in Practical Plant Factory to Capture Metabolite Signature. Front. Plant Sci. 2018, 9, 665. [CrossRef] [PubMed]

17. Zhou, J.; Wang, J.Z.; Hang, T.; Li, P.P. Photosynthetic characteristics and growth performance of lettuce (Lactuca sativa L.) under different light/dark cycles in mini plant factories. Photosynthetica 2020, 58, 740-747. [CrossRef]

18. Kim, M.J.; Moona, J.; Toub, J.C.; Mouc, B.; Waterlanda, N.L. Nutritional value, bioactive compounds and health benefits of lettuce (Lactuca sativa L.). J. Food Comp. Anal. 2016, 49, 19-34. [CrossRef]

19. Barnes, J.; Anderson, L.A.; Gibbons, S.; Philipson, J.D. Echinacea species (Echinacea angustifolia (DC.) Hell., Echinacea pallida (Nutt.) Nutt., Echinacea purpurea (L.) Moench): A review of their chemistry, pharmacology and clinical properties. J. Pharm. Pharmacol. 2005, 57, 929-954. [CrossRef]

20. Tousch, D.; Lajoix, A.; Hosy, E.; Azay-Milhau, J.; Ferrare, K.; Jahannault, C.; Cross, G.; Petit, P. Chicoric acid, a new compound able to enhance insulin release and glucose uptake. Biochem. Biophys. Res. Commun. 2008, 377, 131-135. [CrossRef]

21. Xiao, H.; Wang, J.; Yuan, L.; Xiao, C.; Wang, Y.; Liu, X. Chicoric acid Induces apoptosis in 3T3-L1 preadipocytes through ROS-mediated PI3K/Akt and MAPK signaling pathways. J. Agric. Food Chem. 2013, 61, 1509-1520. [CrossRef]

22. Charvat, T.T.; Lee, D.J.; Robinson, W.E.; Chamberlin, A.R. Design, synthesis, and biological evaluation of chicoric acid analogs as inhibitors of HIV-1 integrase. Bioorg. Med. Chem. 2006, 14, 4552-4567. [CrossRef]

23. Azay-Milhau, J.; Ferrare, K.; Leroy, J.; Aubaterre, J.; Tournier, M.; Lajoix, A.; Tousch, D. Anti hyperglycemic effect of a natural chicoric acid extract of chicory (Cichorium intybus L.): A comparative in vitro study with the effects of caffeic and ferulic acids. J. Ethnopharmacol. 2013, 150, 755-760. [CrossRef]

24. Hernández, I.; Alegre, L.; Van Breusegem, F.; Munné-Bosch, S. How relevant are flavonoids as antioxidants in plants? Trends Plant Sci. 2009, 14, 125-132. [CrossRef]

25. Romani, A.; Pinelli, P.; Galardi, C.; Graziano, S.; Cimato, A.; Heimler, D. Polyphenols in greenhouse and open-air-grown lettuce. Food Chem. 2002, 79, 337-342. [CrossRef]

26. Agati, G.; Matteini, P.; Goti, A.; Tattini, M. Chloroplast-located flavonoids can scavenge singlet oxygen. New Phytol. 2007, 174, 77-89. [CrossRef] [PubMed]

27. Bunning, M.L.; Kendall, P.A.; Stone, M.B.; Stonaker, F.H.; Stushnoff, C. Effects of Seasonal Variation on Sensory Properties and Total Phenolic Content of 5 Lettuce Cultivars. J. Food Sci. 2010, 75, 156-161. [CrossRef] [PubMed]

28. Samuolienè, G.; Sirtautas, R.; Brazaitytè, A.; Duchovskis, P. LED lighting and seasonality effects antioxidant properties of baby leaf lettuce. Food Chem. 2012, 134, 1494-1499. [CrossRef]

29. Loconsole, D.; Cocetta, G.; Santoro, P.; Ferrante, A. Optimization of LED Lighting and Quality Evaluation of Romaine Lettuce Grown in An Innovative Indoor Cultivation System. Sustainability 2019, 11, 841. [CrossRef]

30. Zha, L.; Liu, W.; Yang, Q.; Zhang, Y.; Zhou, C.; Shao, M. Regulation of Ascorbate Accumulation and Metabolism in Lettuce by the Red:Blue Ratio of Continuous Light Using LEDs. Front. Plant Sci. 2020, 11, 704. [CrossRef]

31. Pennisi, G.; Orsini, F.; Blasioli, S.; Cellini, A.; Crepaldi, A.; Braschi, I.; Spinelli, F.; Nicola, S.; Fernandez, J.A.; Stanghellini, C.; et al. Resource use efficiency of indoor lettuce (Lactuca sativa L.) cultivation as affected by red: Blue ratio provided by LED lighting. Sci. Rep. 2019, 9, 14127. [CrossRef]

32. Pennisi, G.; Pistillo, A.; Orsini, F.; Cellini, A.; Spinelli, F.; Nicola, S.; Fernandez, J.A.; Crepaldi, A.; Gianquinto, G.; Marcelis, L.F.M. Optimal light intensity for sustainable water and energy use in indoor T cultivation of lettuce and basil under red and blue LEDs. Sci. Hortic. 2020, 272, 109508. [CrossRef]

33. Pennisi, G.; Orsini, F.; Landolfo, M.; Pistillo, A.; Crepaldi, A.; Nicola, S.; Fernández, J.A.; Marcelis, L.F.M.; Gianquinto, G. Optimal photoperiod for indoor cultivation of leafy vegetables and herbs. Eur. J. Hortic. Sci. 2020, 85, 329-338. [CrossRef] 
34. Cuong, D.M.; Ha, T.W.; Park, C.H.; Kim, N.S.; Yeo, H.J.; Chun, S.W.; Kim, C.; Park, S.U. Effects of LED lights on Expression of Genes Involved in Phenylpropanoid Biosynthesis and Accumulation of Phenylpropanoids in Wheat Sprout. Agronomy 2019, 9, 307. [CrossRef]

35. Ma, G.; Zhang, L.; Kurnia, S.C.; Yamawaki, K.; Asai, T.; Nishikawa, F.; Maezawa, S.; Sato, H.; Kanemitsu, N.; Kato, M. Effect of red and blue LED light irradiation on ascorbate content and expression of genes related to ascorbate metabolism in postharvest broccoli. Postharvest Biol. Technol. 2014, 94, 97-103. [CrossRef]

36. Samuolienè, G.; Brazaitytè, A.; Vaštakaitè, V. Light-Emitting Diodes (LEDs) for improved nutritional quality. In Light Emitting Diodes for Agriculture; Springer: Singapore, 2017; pp. 149-190.

37. Ahn, S.Y.; Kim, S.A.; Baek, K.H.; Yun, H.K. Inhibiting wildfire and inducing defense-related gene expression by LED treatment on Nicotiana benthamiana. J. Plant Pathol. 2013, 95, 477-483.

38. Pennisi, G.; Sanyé-Mengual, E.; Orsini, F.; Crepaldi, A.; Nicola, S.; Ochoa, J.; Fernandez, J.A.; Gianquinto, G. Modelling Environmental Burdens of Indoor-Grown Vegetables and Herbs as Affected by Red and Blue LED Lighting. Sustainability 2019, 11, 4063. [CrossRef]

39. Llorach, R.; Martínez-Sánchez, A.; Tomás-Barberán, F.A.; Gil, M.A.; Ferreres, F. Characterisation of polyphenols and antioxidant properties of five lettuce varieties and escarole. Anal. Methods 2008, 108, 1028-1038. [CrossRef]

40. Singleton, V.L.; Rossi, J.A. Colorimetry of total phenolics with phosphomolybdic-phosphotungstic acid reagents. Am. J. Enol. Vitic. 1965, 16, 144-158.

41. Zhou, C.; Sun, C.; Chen, K.; Li, X. Flavonoids, Phenolics, and Antioxidant Capacity in the Flower of Eriobotrya japonica Lindl. Int. J. Mol. Sci. 2011, 12, 2935-2945. [CrossRef] [PubMed]

42. Milinović, B.; Dragović-Uzelac, V.; Kazija, D.H.; Jelačić, T.; Vujević, P.; Čiček, D.; Biško, A.; Čmelik, Z. Influence of four different dwarfing rootstocks on phenolic acids and anthocyanin composition of sweet cherry (Prunus avium L.) cvs 'Kordia' and 'Regina'. J. Appl. Bot. Food Qual. 2016, 89, 29-37.

43. Brand-Williams, W.; Cuvelier, M.E.; Berset, C. Use of a free radical method to evaluate antioxidant activity. Food Sci. Technol. 1995, 28, 25-30. [CrossRef]

44. Thaipong, K.; Boonprakob, U.; Crosby, K.; Cisneros-Zevallos, L.; Byrne, D.H. Comparison of ABTS, DPPH, FRAP, and ORAC assays for estimating antioxidant activity from guava fruit extracts. J. Food Compost. Anal. 2006, 19, 669-675. [CrossRef]

45. Ou, B.; Hampsch-Woodill, M.; Prior, R.L. Development and Validation of an Improved Oxygen Radical Absorbance Capacity Assay Using Fluorescein as the Fluorescent Probe. J. Agric. Food Chem. 2001, 49, 4619-4626. [CrossRef] [PubMed]

46. Ruiz, K.B.; Rapparini, F.; Bertazza, G.; Silva, H.; Torrigiani, P.; Biondi, S. Comparing salt-induced responses at the transcript level in a salares and coastal-lowlands landrace of quinoa (Chenopodium quinoa Willd). Environ. Exp. Bot. 2017, 139, 127-142. [CrossRef]

47. Borowski, J.M.; Galli, V.; da Silva Messias, R.; Perin, E.C.; Buss, J.H.; Silva, S.D.D.A.; Rombaldi, C.V. Selection of candidate reference genes for real-time PCR studies in lettuce under abiotic stresses. Planta 2014, 239, 1187-1200. [CrossRef] [PubMed]

48. Livak, K.J.; Schmittgen, T.D. Analysis of relative gene expression data using real-time quantitative PCR and the $2-\Delta \Delta C T$ method. Methods 2001, 25, 402-408. [CrossRef] [PubMed]

49. Jishi, T.; Matsuda, R.; Fujiwara, K. A kinetic model for estimating net photosynthetic rates of cos lettuce leaves under pulsed light. Photosynth. Res. 2015, 124, 107-116. [CrossRef]

50. Graamans, L.; Baeza, E.; van Den Dobbelsteen, A.; Tsafaras, I.; Stanghellini, C. Plant factories versus greenhouses: Comparison of resource use efficiency. Agric. Syst. 2018, 160, 31-43. [CrossRef]

51. Flörke, M.; Schneider, C.; McDonald, R.I. Water competition between cities and agriculture driven by climate change and urban growth. Nat. Sustain. 2018, 1, 51-58. [CrossRef]

52. Khanam, U.K.S.; Oba, S.; Yanase, E.; Murakami, Y. Phenolic acids, flavonoids and total antioxidant capacity of selected leafy vegetables. J. Funct. Foods 2012, 4, 979-987. [CrossRef]

53. Shahidi, F.; Ambigaipalan, P. Phenolics and polyphenolics in foods, beverages and spices: Antioxidant activity and health effects-A review. J. Funct. Foods 2015, 18, 820-897. [CrossRef]

54. García-Macías, P.; Ordidge, M.; Vysini, E.; Waroonphan, S.; Battey, N.H.; Gordon, M.H.; Hadley, P.; John, P.; Lovegrove, J.A.; Wagstaffe, A. Changes in the flavonoid and phenolic acid contents and antioxidant activity of red leaf lettuce (Lollo Rosso) due to cultivation under plastic films varying in ultraviolet transparency. J. Agric. Food Chem. 2007, 55, 10168-10172. [CrossRef]

55. Zivcak, M.; Brückova, K.; Sytar, O.; Brestic, M.; Olsovska, K.; Allakhverdiev, S.I. Lettuce flavonoids screening and phenotyping by chlorophyll fluorescence excitation ratio. Planta 2017, 245, 1215-1229. [CrossRef]

56. Loi, M.; Villani, A.; Paciolla, F.; Mulè, G.; Paciolla, C. Challenges and Opportunities of Light-Emitting Diode (LED) as Key to Modulate Antioxidant Compounds in Plants. A Review. Antioxidants 2021, 10, 42. [CrossRef]

57. Vaštakaitè, V.; Viršilè, A.; Brazaitytè, A.; Samuolienè, G.; Miliauskienè, J.; Jankauskienè, J.; Duchovskis, P. Pulsed LED light increases the phytochemical level of basil microgreens. Acta Hortic. 2018, 1227, 579-584. [CrossRef]

58. Vaštakaitè, V.; Viršilè, A.; Brazaitytè, A.; Samuolienė, G.; Jankauskienė, J.; Novičkovas, A.; Duchovskis, P. Pulsed Light-Emitting Diodes for a Higher Phytochemical Level in Microgreens. J. Agric. Food Chem. 2017, 65, 6529-6534. [CrossRef]

59. Granato, D.; Santos, J.S.; Maciel, L.G.; Nunes, D.S. Chemical perspective and criticism on selected analytical methods used to estimate the total content of phenolic compounds in food matrices. Trends Anal. Chem. 2016, 80, 266-279. [CrossRef] 
60. Rouphael, Y.; Petropoulos, S.A.; El-Nakhel, C.; Pannico, A.; Kyriacou, M.C.; Giordano, M.; Troise, A.D.; Vitaglione, P.; De Pascale, S. Reducing energy requirements in future bioregenerative life support systems (BLSSs): Performance and bioactive composition of diverse lettuce genotypes grown under optimal and suboptimal light conditions. Front. Plant Sci. 2019, 10, 1305. [CrossRef]

61. Pérez-López, U.; Sgherri, C.; Miranda-Apodaca, J.; Micaelli, F.; Lacuesta, M.; Mena-Petite, A.; Quartacci, M.F.; Muñoz-Rueda, A. Concentration of phenolic compounds is increased in lettuce grown under high light intensity and elevated $\mathrm{CO}_{2}$. Plant Physiol. Biochem. 2018, 123, 233-241. [CrossRef]

62. Michiels, J.A.; Kevers, C.; Pincemail, J.; Defraigne, J.O.; Dommes, J. Extraction conditions can greatly influence antioxidant capacity assays in plant food matrices. Food Chem. 2012, 130, 986-993. [CrossRef]

63. Sharma, A.; Shahzad, B.; Rehman, A.; Bhardwaj, R.; Landi, M.; Zheng, B. Response of Phenylpropanoid Pathway and the Role of Polyphenols in Plants under Abiotic Stress. Molecules 2019, 24, 2452. [CrossRef]

64. Barros, J.; Escamilla-Trevino, L.; Song, L.; Rao, X.; Serrani-Yarce, J.C.; Palacios, M.D.; Engle, N.; Choudhury, F.K.; Tschaplinski, T.J.; Venables, B.J.; et al. 4-Coumarate 3-hydroxylase in the lignin biosynthesis pathway is a cytosolic ascorbate peroxidase. Nat. Commun. 2019, 10, 1994. [CrossRef]

65. Zulueta, A.; Esteve, M.J.; Frígola, A. ORAC and TEAC assays comparison to measure the antioxidant capacity of food products. Food Chem. 2009, 114, 310-316. [CrossRef]

66. Cao, G.; Sofic, E.; Prior, R.L. Antioxidant capacity of tea and common vegetables. J. Agric. Food Chem. 1996, $44,3426-3431$. [CrossRef]

67. Ou, B.; Huang, D.; Hampsch-Woodill, M.; Flanagan, J.A.; Deemer, E.K. Analysis of antioxidant activities of common vegetables employing Oxygen Radical Absorbance Capacity (ORAC) and Ferric Reducing Antioxidant Power (FRAP) assays: A comparative study. J. Agric. Food Chem. 2002, 50, 3122-3128. [CrossRef]

68. Đorđević, T.M.; Šiler-Marinković, S.S.; Dimitrijević-Branković, S.I. Effect of fermentation on antioxidant properties of some cereals and pseudo cereals. Food Chem. 2010, 119, 957-963. [CrossRef]

69. Lien, E.J.; Ren, S.; Bui, H.; Wang, R. Quantitative structure-activity relationship analysis of phenolic antioxidants. Free Radic. Biol. Med. 1999, 26, 285-294. [CrossRef]

70. Fu, W.; Li, P.; Wu, Y.; Tang, J. Effects of different light intensities on anti-oxidative enzyme activity, quality and biomass in lettuce. Hort. Sci. (Prague) 2012, 39, 129-134.

71. Estevéz, I.H.; Hernandez, M.R. Plant Glutathione S-transferases: An overview. Plant Gene 2020, 23, 100233. [CrossRef]

72. Szymanska, R.; Slesak, I.; Orzechowska, A.; Kruk, J. Physiological and biochemical responses to high light and temperature stress in plants. Environ. Exp. Bot. 2017, 139, 165-177. [CrossRef] 